HANNA KARASZEWSKA

JOANNA RAJEWSKa DE MEZER

EWELINA SILECKA-MAREK

Uniwersytet im. Adama Mickiewicza

$w$ Poznaniu

\title{
PEDAGOGICAL AND LEGAL ACTIVITIES TAKEN IN POLAND TOWARDS PEOPLE ADDICTED TO ALCOHOL
}

\begin{abstract}
AвStract. Karaszewska Hanna, Rajewska de Mezer Joanna, Silecka-Marek Ewelina, Pedagogical and Legal Activities Taken in Poland Towards People Addicted to Alcohol [Pedagogiczne i prawne działania podejmowane w Polsce wobec osób uzależnionych od alkoholu]. Studia Edukacyjne nr 47, 2018, Poznań 2018, pp. 209-229. Adam Mickiewicz University Press. ISSN 1233-6688. DOI: 10.14746/se.2018.47.14

The issue of alcohol consumption, addiction to it, and causes and effects of this phenomenon have already been explored many times. The article describes current pedagogical and legal activities taken in Poland towards people addicted to alcohol and related controversy. The authors drew attention to a number of problems concerning with alcohol addiction for an alcohol abuse person and his family. Starting from the current law on upbringing in sobriety and counteracting alcoholism because it takes up issues related to treatment, rehabilitation and social reintegration of people addicted to alcohol. There are institutions established on its basis and take up actions aimed at diagnosing the problem of an individual's addiction to alcohol, leading to a ruling and requiring the person addicted to alcohol to undergo treatment. In the article the stages of treatment have been described in detail, requriments, important person for example probation officer and possible to receive treatment from non-governmental organizations that help those addicted and thus create an option for those addicted to alcohol to self-organize.

The authors emphasized that the process of freeing from alcohol addiction is incredibly difficult and sometimes prolonged. Thus, the compulsory character of rehab treatment sparks a lot of controversy, as it contradicts the right to self-determination, i.e. independent decision of the person addicted to take up the treatment. There is a need to search new solutions in this respect, develop tools that increase the effectiveness of activities taken towards those addicted and exchange experiences on the global scale.
\end{abstract}

Key words: addiction, addiction of alcohol, sobriety, counteracting alcoholism, treatment 
Do you drown your sorrows in alcohol? Don't; they can swim very well.

Yves Mirande

\section{Introduction}

The issue of alcohol consumption, addiction to it, and causes and effects of this phenomenon have already been explored many times. The importance of this subject is underlined by both theoreticians and practitioners dealing with the topic of addiction and working with those addicted. Alcohol addiction is an issue on the global scale.

For the purpose of this paper, it is worth taking a look at the fifth version of the DSM classification (DSM-5) published by the American Psychiatric Association (APA).

In this classification, "alcohol abuse" and "alcohol addiction" have been listed under one diagnostic category characterized with various levels of the intensity of disorders. ${ }^{1}$ To diagnose a mild disorder related to the Alcohol Use Disorder (AUD), two out of 11 criteria have to be fulfilled, ${ }^{2}$ whereas previously it was enough for just one criterion to be met in order to diagnose alcohol abuse. ${ }^{3}$ The new definition approach to "alcohol use disorders" and "disorders caused by using alcohol" can also be found in the ICD-11 classification.

${ }^{1}$ American Psychiatric Association. Diagnostic and statistical manual of mental disorders (DSM-5), APA, Washington 2013.

2 1. Frequent alcohol consumption in larger quantities or for a longer time than planned. 2. Persistent desire to drink alcohol or unsuccessful attempts at limiting or controlling drinking that accompanies it. 3. Devoting a lot of time to activities related to obtaining and drinking alcohol, and eliminating the consequences of drinking. 4. Craving for alcohol or a strong desire or need to drink. 5. Recurring alcohol consumption causing negligence of one's major duties at work, school or home. 6. Alcohol consumption in spite of continuous or recurring social and interpersonal problems caused or deepened by alcohol. 7. Limiting or rejecting important social, professional or leisure activities due to alcohol. 8. Returning to alcohol consumption in situations of threat and physical danger. 9. Alcohol consumption in spite of continuous or recurring physical or psychological problems, probably caused or deepened by alcohol. 10. Building alcohol tolerance related to the need of a much higher alcohol intake (up to the point of poisoning) in order to achieve the desired effect or a visibly smaller effect of using the same amount of alcohol. 11. Experiencing an abstinence syndrome that is related to:

- the manifestation of symptoms characteristic of this syndrome or

- use of alcohol (or other similar substances, e.g. benzodiazepine) in order to decrease or avoid these symptoms.

${ }^{3}$ J. Heitzman, B. Łoza, W. Kosmowski, Classification of mental disorders - a conceptual framework for the ICD11, Psychiatria Polska 2011, 45, p. 941-950. 
In Poland, the psychobiosocial model of addiction has been prevailing for many years now. ${ }^{4}$ It allows one to understand the essence of addiction and the functioning of people addicted to alcohol. It includes three typical pathological mechanisms that make up an addiction together with accompanying phenomena and factors that activate these mechanisms.

They occur as a result of an intensive psychopharmacological effect induced by alcohol, enhanced with intra - and interpersonal experiences, activated with specific external circumstances: situational (situations of stress and increased risk, permanent damage to important social relations and negative social consequences of harmful alcohol consumption in the past) and internal sources (damage to one's organism, somatic and psychological illnesses, deficit of practical life skills and destructive life orientation). ${ }^{5}$

It is estimated that a statistical Pole drinks an average of 9.37 litres of $100 \%$ alcohol a year. As indicated by the data of the State Agency for the Prevention of Alcohol-Related Problems (PARPA), in 2016 the structure of alcoholic drinks consumption was the following: spirits $34.2 \%$, wine and mead $7.4 \%$, and beer $58.4 \%{ }^{6}$

According to the data of the Institute of Psychiatry and Neurology, $11.9 \%$ of adult population (people aged 18-64), or almost 3 million people, use alcohol in Poland, of which 600,000 people are addicted (2.4\%). 20.5\% men and $3.4 \%$ women experience disorders related to alcohol consumption. These problems are intensified mostly in the male population aged $40-49$ $(27.2 \%){ }^{7}$

Similarly to the adult part of the society, alcoholic beverages are also the most widespread psychoactive substance among school-age adolescents. In $2015,83.8 \%$ of third-grade junior high school students and $95.8 \%$ of secondgrade high school students declared that they consume alcohol. ${ }^{8}$

Drinking alcohol as such is not harmful; it becomes harmful when psychological or somatic damage is diagnosed as a result of substance abuse. The most dramatic consequence of drinking is developing an addiction to alcohol.

\footnotetext{
${ }^{4}$ More on the topic of the addiction model in: B.T. Woronowicz, Geneza, terapia, powrót do zdrowia, Warszawa 2009; L. Cierpiałkowska, M. Ziarko, Psychologia uzależnień - alkoholizm, Warszawa 2010; I. Pospiszyl, Patologie spoteczne, Warszawa 2008.

${ }^{5}$ E. Włodarczyk, Społeczny wymiar problemu alkoholowego kobiet. Obraz i instytucjonalne reakcje środowiska wielkomiejskiego, Poznań 2017, p. 59.

${ }^{6} \mathrm{http}: / /$ www.parpa.pl/index.php/badania-i-informacje-statystyczne/statystyki, [accessed: 23.01.2018].

7 EZOP research in the years 2010-2011, quoted after W.S. Zgliczyński, Alkohol w Polsce, INFOS Zagadnienia społeczno-gospodarcze, 2016, 11(215).

8 J. Sierosławski, Używanie alkoholu i narkotyków przez młodzież szkolną, Raport z ogólnopolskich badań ankietowych zrealizowanych w 2015 r., Europejski Program Badań Ankietowych w Szkołach, ESPAD, p. 19, (pdf).
} 
Drinking becomes a problem not only for the person addicted, but also for their entire family system. Family functioning is disorganized, its particular functions are disrupted, and family bonds become pathological in nature, as they are based on the effort to keep the fact that one of its members is addicted a secret. Negative behaviours, including violence, that require a response may occur. Those addicted usually do not want to undergo treatment; they use defensive mechanisms, without noticing the problem of their own addiction and the need to make a change.

The process of freeing oneself from alcohol addiction is incredibly difficult and sometimes long-lasting, which is why it requires the help and involvement of one's family, friends, specialists from many fields, therapists and institutions appointed by law to support an individual and their family in case such a problem occurs.

\section{State Policy on the Issue of Alcohol Addiction: Statutory Solutions}

The Polish state acts on a wide scale in the area of preventing and supporting those affected by alcohol addiction, and the law on upbringing in sobriety and counteracting alcoholism ${ }^{9}$ is the basis for taking up these activities. It is linked to a variety of other acts of law that regulate issues resulting from the appearance of the problem of an individual's addiction, their social functioning, influence their addiction has on their closest environment, spouse, offspring, and completing particular social roles by them.

The character of these activities can be both legal, and pedagogical and therapeutic, and the aim of the law on upbringing in sobriety is to counteract alcoholism by shaping social policies adequately.

The law emphasizes the need to pay attention to the genesis of the addiction, thus creating conditions that are beneficial for fulfilling human needs. At the same time, it is vital to counteract reaching out for alcohol, perceived as an antidote for a frustration caused by one's inability to deal with everyday life difficulties. It is important to have an adequate information campaign on the issue of addiction, its features and consequences of alcohol abuse that are often difficult to reverse. The lawmakers also point our attention to the state's activities that interfere with the liberty to conduct business related to alcohol production meant for consumption and the advisability of limiting access to alcohol beverages.

${ }^{9}$ Law of 26 October 1982 on upbringing in sobriety and counteracting alcoholism (Journal of Law 2016 item 487 with changes). 
The law on upbringing in sobriety and counteracting alcoholism also regulates the issue of great importance for the struggle against addiction that deals with preventing negative effects of alcohol abuse and their elimination (including family violence). It takes up issues related to treatment, rehabilitation and social reintegration of people addicted to alcohol. ${ }^{10}$

It was the State Agency for the Prevention of Alcohol-Related Problems (PARPA) that was appointed for the correct organization of statutory activities and completion of objectives. Its tasks include, above all, preparing and giving opinion on drafts of legal acts that regulate the topics related to activities taken up to counteract the problem of alcohol addiction and its consequences. By cooperating with both administrative bodies and entities operating in the non-governmental (non-profit) sector as far as educational and informative activities in the subject of prevention and addiction rehab are concerned, the Agency coordinates and initiates activities related to addiction treatment. It cooperates with international institutions and organisations that carry out preventive and therapeutic activities. ${ }^{11}$

Carrying out activities related to the prevention and solving of alcohol problems, and social integration of people addicted to alcohol is one of a commune's (Polish gmina's) own tasks. In order to complete statutory rulings, a communal prevention programme is created in each commune. Within the programme, objectives related to the prevention and solving of alcohol problems, as defined by the National Health Programme, are solved. The programme is passed every year by the commune council and completed by the social welfare centre or another unit.

As part of its own tasks, the commune carries out activities aimed at providing therapeutic and rehabilitation help to people addicted to alcohol, providing psychosocial and legal assistance (including protection against violence) to families affected by the alcohol problem and carrying out informative and educational activities of preventive nature as far as solving alcohol problems and counteracting drug addiction are concerned. A commune's own tasks also include supporting activities of institutions, associations and people that serve in favour of solving alcohol problems. ${ }^{12}$

Activities related to the prevention and solving of alcohol problems are carried out by proper authorities, i.e. communal commissions for solving alcohol problems. They take up actions aimed at diagnosing the problem of an individual's addiction to alcohol, leading to a ruling and requiring the person addicted to alcohol to undergo treatment at a rehab centre.

\footnotetext{
${ }^{10}$ Ibidem.

11 Art. 3 of Ibidem.

12 Art. 41section 1 of Ibidem.
} 
Members of the commission are trained in the topics pertaining to the prevention and solving of alcohol problems. The law on upbringing in sobriety that is in effect in Poland does not, however, provide for a training programme or define any topics that must be covered as part of it. A general programme of basic training for communal commissions for solving alcohol problems was prepared by the State Agency for the Prevention of Alcohol-Related Problems. The authors of the recommendation were motivated by the idea which suggests that the competences and skills of people working in communal commissions should be closely linked to the tasks defined for it by the law. ${ }^{13}$ Taking into account the joint character of decision-making by the communal commission and joint work on the communal programme, it is important that the members of the commission, irrespective of their education and major, have the same level of interdisciplinary preparation. ${ }^{14}$ The recommended training programme for a member of the commission includes thematic blocks on: alcohol addiction, risky and harmful drinking, co-addiction, family violence, help for harmed children and children from families affected by the alcohol problem, preventive measures towards children and adolescents, and legal issues. The blocks were enriched with tips on the above-mentioned topics.

PARPA also recommends that people of diverse and complementary competences and representatives of communal services who can join the completion of the communal programme for solving alcohol problems directly (e.g. police officers, social workers, representatives of non-governmental organizations, schools, health service entities, as well as employees of rehab counselling services and specialists in prevention) be members of the commission. It is recommended to divide the commission into problem teams, e.g. a team for counteracting family violence or a team for motivating people to undergo treatment. The above would allow each member of the commission to participate in activities in line with their competences, and thus lead to a better professionalization of work and reach of activity. ${ }^{15}$

Family members of people addicted to alcohol who are affected by the consequences of alcohol abuse by their relative are provided with free-ofcharge health benefits in the form of therapy and co-addiction rehabilitation. Preventive measures are also applied to them. To a large extent, the lawmakers focused on children of those addicted. The law guarantees them free psy-

${ }^{13}$ Rozwiązywanie problemów alkoholowych w gminie - ramowy program szkolenia dla gminnych komisji rozwiązywania problemów alkoholowych, Państwowa Agencja Rozwiązywania Problemów Alkoholowych, Warszawa 2016, http://www.parpa.pl/images/file/szkolenia_srodek_09_06.pdf [accessed: 18.12.2017].

${ }^{14}$ Ibidem, p. 5.

${ }^{15}$ Ibidem, p. 6, http://www.parpa.pl/images/file/szkolenia_srodek_09_06.pdf [accessed: 18.12.2017]. 
chological and sociotherapeutical help in specialized counselling clinics, and educational care and rehabilitation facilities. It is crucial that the lawmakers applied a solution where it is possible to provide children with help even against the will of their intoxicated parents or guardians. ${ }^{16}$

If alcohol abuse by a child's parents or legal guardians poses a threat to their well-being (life, health, feeling of security, right to fulfil elementary needs), the state can intervene in executing parental authority or custody of a minor. Depending on the level of threat or violation of a minor's well-being by their parents, a family court can use measures that limit parental authority ${ }^{17}$ or deprive parents of child custody in case of serious abuse or negligence $^{18}$. As part of limiting parental authority, the court can oblige parents to cooperate with a family assistant or direct them to a facility or specialist dealing with family therapy, counselling or providing a family with other type of necessary assistance, at the same time indicating the way to control the completion of the ruling issued. ${ }^{19}$ Another measure of controlling how parental authority is executed by a parent who does not fulfil their duties due to their addiction is to decide that permanent surveillance will be carried out by a court-appointed guardian. ${ }^{20}$ Their task is to control how parents obey the obligations set by the court with regard to the adequate execution of their parental authority over their child and support them in their role as parents. Assistance and support in keeping the resolution to stay sober are particularly important in case of parents addicted to alcohol or other psychoactive substances.

On the other hand, if a legal guardian does not execute the obligations that they were assigned and violates the well-being of a child that is in their custody by abusing alcohol, it is a basis for releasing them compulsorily from custody ${ }^{21}$.

16 Art. 23 of Ibidem.

17 Limiting parental authority regulated in art. 109 of the Family and Guardianship Code law of 25 February 1964 (Journal of Law of 2017 item 682 with changes) leads to its limitation, and can be carried out via: controlling the way parental authority is executed towards a child, need to cooperate with a family assistant, undergoing therapy and treatment, submitting to surveillance by a family guardian or having the child placed in a foster family.

18 When parental authority cannot be executed due to a permanent hindrance, or if parents abuse their parental authority or there is a gross negligence of parents' duties towards their child, the guardianship court will deprive parents of their parental authority - art. 111 of the Family and Guardianship Code law of 25 February 1964 (Journal of Law of 2017 item 682 with changes).

19 Art. 109 § 2 point 1 of the Family and Guardianship Code law.

20 Art. 109 \$2 point 3 of the Family and Guardianship Code law.

21 The guardianship court will discharge the guardian if due to factual or legal impediments the guardian is unable to execute custody or commits acts or negligence that violate the well-being of the person in their custody - art. $169 \S 2$ of the of the Family and Guardianship Code law of 25 February 1964 (Journal of Law of 2017 item 682 with changes). 


\section{Proceedings Against those Addicted to Alcohol}

In Poland, proceedings related to alcohol abuse are commenced on the following premises: alcohol is abused by the participant of the proceedings and - very importantly - the abuse leads to disruption of family life, moral corruption of minors, evading work or regular public peace or order offences. ${ }^{22}$

Proceedings related to alcohol abuse are carried out by communal commissions for solving alcohol problems. The commission can be notified by a private person or a public institution (e.g. police, school, social welfare centre, or an interdisciplinary team for counteracting family violence, or a working group acting within its scope). ${ }^{23}$

The first stage of the proceedings is to direct a person abusing alcohol to an examination by an expert in order for them to issue an opinion on the subject of alcohol abuse and indicate the type of treatment facility. The opinion should be issued by two experts, a psychologist and a psychiatrist or an addiction psychotherapist. If according to the opinion the person that underwent the examination is addicted to alcohol, they can be required to undergo treatment in a full-time or part-time addiction rehab facility.

Those addicted often deny that the problem of addiction is a fact and refuse to take up treatment or they first seem to agree, and then do not appear at their arranged therapeutic meetings. If an addicted person does not voluntarily take up treatment activities, a district court adjudicates that they are obliged to undergo treatment in a rehab facility (it is then called a judicial obligation to undergo treatment). Proceedings in court are instigated after a motion is filed by the communal commission for solving alcohol problems or by a prosecutor. The motion has to be accompanied with documentation gathered during the commission's proceedings and an expert's opinion if there was an examination carried out by an expert. ${ }^{24}$

If it was impossible to carry out an examination and issue an opinion that is necessary for the case, the court adjudicates that the defendant should undergo adequate examination or it can adjudicate that the person

${ }^{22}$ As it thus results from art. 24 of the law of 26 October 1982 on upbringing in sobriety and counteracting alcoholism (Journal of Law 2016 item 487 with changes), in order for proceedings on alcohol abuse to be instigated, apart from the fact of alcohol abuse itself, it is necessary for some negative effects of social character harming an individual (not fulfilling social roles, evading from work), as well as other members of society (moral corruption of minors, causing disruption of family life: not satisfying its needs, negligence, violence) to occur.

${ }^{23}$ K. Łukowska, Zobowiazanie do leczenia odwykowego - informator dla rodzin, Warszawa 2014, p. 4 .

${ }^{24}$ Art. 26 section 3 of the Law of 26 October 1982. 
examined should be sent to a treatment facility for observation (for a period of between 2 to maximum 6 weeks). As part of the examination, the person who is the subject of the proceedings is obliged to undergo psychological and psychiatric tests, and procedures necessary to carry out basic laboratory tests.

The court summons the person obliged to undergo rehab treatment to turn up on a given day at a given rehab facility in order to start treatment. In case the person obliged to do so evades this duty, the court can order to take them in for treatment at a rehab facility by force.

The court obligation for treatment is valid for two years, and when this period expires, the procedure has to be restarted and carried out again. It should be noted that the person who did not take up or complete treatment is not punishable, because the above procedure is not within the scope of criminal proceedings. ${ }^{25}$

More and more controversies arise among specialists who work with people addicted to alcohol due to the use of compulsion in order for the addicted person to submit to rehab treatment. The effectiveness of treatment procedures taken up unwillingly and without conviction of the subject is undermined. High costs of administrative and then court proceedings related to obliging those addicted to alcohol to undergo treatment are pointed to, as well as the lack of long-term effects of treatment when the patient is not willing, motivated or convinced of the need to refrain themselves from consuming substances that are harmful for them. Many of those sent to forced treatment return to their addiction after a period of abstinence during their stay at a rehab facility. As shown by statistics, slightly over a half of people obliged by court to take up treatment actually start it, and out of that group less than $50 \%$ finish the basic therapy programme. ${ }^{26}$

The lawmakers did not define the duration of treatment, leaving it thus up to those in charge of each patient, allowing it to be evaluated individually in every single case whether the objective was achieved. Regulations only state the maximum length of treatment which cannot be longer than 2 years from the moment of the decision coming into effect. It is possible for the court to decide about the treatment obligation to cease earlier than planned if it is successful. ${ }^{27}$ The court can also change its decisions as far as the type of rehab facility is concerned, adjusting the types of activities and measures to individual needs.

${ }^{25}$ K. Łukowska, Zobowiazanie do leczenia odwykowego - informator dla rodzin, p. 10.

${ }^{26}$ Ibidem, p. 11.

${ }^{27}$ The court takes action following the request of: the patient, treatment facility, guardian, prosecutor or ex officio, after consulting with people carrying out the treatment or therapy in the facility where the patient is staying. 


\section{Court-Appointed Guardians Working with People Addicted to Alcohol}

The court can appoint family guardians to supervise people obliged to undergo rehab treatment. From the point of view of expected benefits for the subjects in care, their families and even the whole local community, it is important to define the role of the court-appointed guardian and the methods they will use while working with defendants.

As pointed out by A. Węgliński, a guardian who supports a person supervised in the process of giving up on their addiction should understand the changes that occur in that person's mentality and behaviour very well, precisely identify their strengths and weaknesses, as well as the difficulties they may come across that result from their attempts at dealing with the addiction and effectively fulfilling their duties resulting from the adjudication. ${ }^{28}$

A guardian's role is two-dimensional:

- On the one hand, a guardian can influence the addicted person's motivation to take up and continue treatment

- On the other hand, a guardian should also seek institutions, people, organisations that can help the addicted person solve their problems and difficulties. A guardian's role is thus to control, help treat, prevent and aid..$^{29}$

It is very important for the guardian to be able to keep some balance between these functions. As M. Grzegorzewska once noticed, the role of a cour$\mathrm{t}$-appointed guardian comes down to being an educator on court premises. The supervision is of very specific character, because it involves a person that was adjudicated specialist treatment by experts. This means that the guardian works with an ill person who denies their own addiction. However, irrespective of the educative compulsion experienced by the defendant and the need for them to comply with duties enforced by the court, a guardian should fulfil their pedagogic mission.

In direct interactions aimed at aiding, reintegration and education, it is particularly essential to beat or overcome the supervised person's fears, resistance, and sometimes even hostility and aversion towards the guardian whom they associate with the court and judiciary, especially in the first phase of cooperation. In particular, these situations happen when a court-appointed guardian's work is dominated by control activities that only consist in making sure that the defendant fulfils their obligations imposed by the court (...). At every stage of working with a supervised person, a court-appointed guardian must search for consensus, understanding, compromise between the expectations of the judiciary and the possibilities and resources of the defendant. ${ }^{30}$

${ }^{28}$ A. Węgliński, G. Kuziora, W poszukiwaniu wychowującej kurateli sądowej, Lublin 2016, p. 26.

${ }^{29}$ T. Jedynak, K. Stasiak (red.), Zarys metodyki kuratora sądowego, Warszawa 2014, p. 6.

30 A. Węgliński, Zasoby osobiste $i$ kompetencje zawodowe kuratorów sądowych niezbędne w pracy z osoba dozorowana z problemem alkoholowym, Lubelski Rocznik Pedagogiczny, 2013, XXXII, p. 344. 
These words acquire special significance if the supervised person is addicted to alcohol, and the course of them giving up on their addiction will depend on the guardian's knowledge and personal and profession competences to a large extent. A guardian should be able to diagnose which stage of addiction their supervised person is at in order to objectively evaluate the symptoms in their attitudes and behaviours, be prepared for incomprehensible, irrational reactions of a person living in the alcoholic world of illusions and denial, and manifest an undistorted attitude of kindliness towards them out of concern for their psychophysical health and rebuilding or building correct relationships with people close to them. A vast majority of people return to addictive drinking due to negative relations with their environment.

It is a very difficult and responsible task for the guardian, too, as they have to be authentic, kind and supportive, and at the same time demanding, challenging and appraising their defendants with unrelenting consistency (subject literature refers to this attitude as the so-called "tough love"). Thus, in view of all those challenges that a guardian and an addicted defendant face, it seems most justified to act according to the casework procedure.

Many papers have been written on casework and rules that govern it. ${ }^{31}$ One can be under the impression that the topic is no longer current and it makes no sense to repeatedly write and remind the basics that are known to those who work with their subjects in areas where they help or resocialise them, etc. The casework strategy has been transformed and modified; it has been defined in various ways in theoretical approaches, yet its principal assumption has remained unchanged. It refers to organising an environment that motivates an individual to take up activities and stimulating their individual resources that foster their activity and development.

Currently, social services use casework mainly when they work with three categories of people who: 1) have run out of their energy and options to solve a problem, and their only way to deal with a difficult situation is to use a caseworker's help that would assist them in finding a solution and guide them; 2 ) are unable to use the offer of social

${ }^{31}$ Among many rules assigned to casework, authors who support it enumerate the following as indispensable: the rule of individualisation, acceptance and respect, and holding the supervised person in esteem. These may seem obvious in care-taking and resocialisation work; however, it is most important for the guardian to be fully convinced about the need and legitimacy of using them, and believe that they can contribute to a change in a defendant's way of thinking and behaving with their help and support. More in: A. Bałandynowicz, Probacja. Wychowanie do wolności, Grodzisk Mazowiecki 1996; M. Kalinowski, Vademecum rodzinnego kuratora sądowego, Warszawa 1984; Z. Ostrihanska, A. Greczuszkin, Praca z indywidualnym przypadkiem $w$ nadzorze rodzinnego kuratora sądowego, Lublin 2000; K. Sawicka, Probacyjne środki w profilaktyce i resocjalizacji nieletnich, [w:] Probacyjne środki polityki karnej - stan i perspektywy, oprac. B. Cichonska, Warszawa 2001. 
services due to their mental or physical limitations; 3) have been under prolonged stress, which has made them unable to solve even simple problems ${ }^{32}$.

People with the alcohol problem can be addressees of this method. According to A. Bałandynowicz, if methodological work with them is based on casework, it will be possible to trigger motivation in them to work on themselves and atone for moral and social damage caused by harmful drinking. ${ }^{33}$ For quite some time now, the method of motivational dialogue authored by William R. Miller and Stephen Rollnick ${ }^{34}$ is used when working with people addicted to psychoactive substances (according to DSM-5 substance use disorders, i.e. "disorders linked to using psychoactive substances").

Motivational dialogue is a target-oriented way of communication based on cooperation, paying special attention to the language of change. Its objective is to strengthen personal motivation and commit one to achieve a particular objective through identifying and examining the person's own reasons to change in an atmosphere of acceptance and compassion. ${ }^{35}$

Motivational dialogue clearly uses the assumptions of Carl Rogers's therapy focused on the patient where the relationship between the therapist and their client influences the effects most. A court-appointed guardian who openly talks with their subject and allows themselves to present their real emotions and reactions, can encourage the person they supervise to adopt a similar attitude with their behaviour and this can mean social reinforcement for them. A guardian should allow themselves to be on equal terms with their defendant, show ambivalence and elicit the so-called language of change. ${ }^{36}$ When

${ }^{32}$ A. Węgliński, Motywowanie skazanych z problemem alkoholowym do samowychowania w warunkach wolnościowych, Lubelski Rocznik Pedagogiczny, 2014, XXXIII quoted after: D. Lalak, Teoretyczny i praktyczny sens metody indywidualnych przypadków [w:] Pedagogika społeczna, red. T. Pilch, L. Lepalczyk, Warszawa 1995, p. 230.

${ }_{33}$ A. Bałandynowicz, Destygmatyzacja tożsamości dewiantów jako zmiana czasowa i interpersonalna w polifunkcyjnym modelu probacji, [w:] Tożsamość osobowa dewiantów a ich reintegracja społeczna, cz. L, red. A. Kieszkowska, Kraków 2011, p. 41 and further.

${ }_{34}$ Motivational dialogue is a method whose effectiveness in individual work has been well documented (over 1,000 publications in the EBSCO database). The theoretical basis are clinical studies on people who abuse or are addicted. Motivational dialogue is applied in individual and group work, in cognitive-behavioural therapy, in systemie therapy. It can be used when working in the field of psychotherapy, social welfare, resocialisation, medicine, education and many other domains.

35 See R.W. Miller, S. Rollnick, Dialog motywujacy. Jak pomóc ludziom w zmianie, Kraków 2014, p. 55; J.M. Jaraczewska, M. Adamczyk-Zientara (red.), Dialog motywujący. Praca z osobami uzależnionymi behawioralnie, Warszawa 2015.

${ }^{36}$ Ambivalence is close the the notion of cognitive dissonance or intrapsychic crisis, or it can reflect defense mechanisms. If no solution is found for a longer time, it can be a cause for stagnation, but it can also contribute to a change, or to seeking solutions. A person who experiences ambivalence can feel contradictory emotions, thoughts and needs. The longer the duration of 
talking to a client, commonly known and used therapeutic techniques are applied, such as mirroring, rephrasing, giving feedback, asking open questions, boosting self-esteem, etc.; however, the effectiveness of motivational dialogue still mainly depends on the way the client is treated, ability to build an atmosphere and relation that support them in their aspiration for a change. ${ }^{37}$

When a guardian completes the above-mentioned objectives, they may (but do not have to) be hindered by the double role they play, because apart from supporting the alcohol-addicted person whom they supervise in their efforts to take up treatment, a guardian is also obliged to carry out other duties assigned by the court. On the other hand, however, empathic engagement in their relation with a defendant may also translate into them performing other tasks better.

To sum up, a guardian is entitled to summon their addicted subject and require them to act in a way aimed at shortening their treatment, submit motions to courts aimed at changing their decisions as far as the type of the rehab facility is concerned, as well as aimed at ceasing the obligation to undergo treatment.

When supervising a person with the alcohol problem, a guardian also has other tasks, for example:

- Keeping regularly in touch with the person obliged to undergo treatment;

- Providing them with necessary assistance in solving life difficulties (starting and continuing treatment);

- When required, cooperating with local state administration authorities and social organizations in order to ensure that the person undergoing treatment or their family receives appropriate help, in particular through facilitating employment, providing temporary accommodation and material benefits;

ambivalence, the greater the helplessness towards a change and risk of consolidating negative behaviours, for example those linked to the addiction.

Language of change sounds out a client's readiness for making changes in their behaviour; it is a verbalized form of automotivation. It can be expressed through a desire for something: "I want to drink less", abilities: "I would be able to drink less if I did not meet my friends who drink", reasons to change: " I could lose less money or be in a relationship if I did not drink ", a need: "I have to do something with myself". The language of change used can also be motivating, such as: I intend to; I am willing to; I am going to give up drinking tomorrow. See C. Barański, Dialog motywujący w pracy z grupami osób podejmujących zachowania ryzykowne, Psychoterapia, 2016, 3, p. $40-42$.

37 A. Węgliński wrote extensively on motivational dialogue, its rules, stages and how it can be used at work by court-appointed guardians, Motywowanie skazanych z problemem alkoholowym do samowychowania w warunkach wolności dozorowanej, Lubelski Rocznik Pedagogiczny, 2014, XXXIII and only some of the issues discussed there have been quoted in this paper due to its limitations. 
- Cooperating with a rehab facility so that objectives are achieved via treatment;

- Encouraging their subject who undergoes treatment to contact appropriate healthcare facilities and mutual-aid organizations for people addicted to alcohol;

- Maintaining contact with the family (those who live in one household) of their subject who undergoes treatment;

- Influencing the environment where the person who undergoes treatment stays or where they are to return, in particular shaping the appropriate attitude towards them;

- Submitting written reports to the court on the progress of treatment within deadlines defined by the court, yet not less frequently than once every two months;

- Notifying the court of the need to take other necessary actions.

However, "apart from shaping a sober attitude and limiting their alcohol intake regularly, in a relatively short period of time, an alcohol-addicted person under supervision will have to obey the rules of their functioning strictly set by the court and learn a lot about things that so far alcohol "managed for them". ${ }^{38}$

\section{Entities Operating as Part of the Support System for those Affected by the Issue of Alcohol Addiction}

In the system of supporting an addicted person and their family, there are various institutions that cooperate: commissions for solving alcohol problems, welfare centres, municipal centres for family support, courts and court-appointed guardians, educational institutions, healthcare facilities, nongovernmental organizations. The network of institutions also includes rehab facilities for alcohol addicts, for example alcohol addiction and co-addiction rehab clinics, addiction rehab clinics, 24-hour alcohol addiction rehab wards, 24-hour addiction rehab wards, day-care alcohol addiction rehab wards, daycare addiction rehab wards, wards for treating alcohol abstinence syndromes and hostels for people addicted to alcohol. In some cities, there are counselling points organized by commune governments, welfare centres, teetotal associations, as well as churches and religious organizations. These are supposed to be places where people requiring assistance are provided with first aid, that are easily accessible and from where they will be directed to an institution

${ }^{38}$ A. Węgliński, Motywowanie skazanych z problemem alkoholowym. 
providing specialized care ${ }^{39}$ People dealing with an addiction problem can also use a helpline where they will be provided with information about possible treatment, and above all where they will be encouraged to act.

Rehab facilities that provide full-time services include alcohol addiction and co-addiction rehab clinics and addiction rehab clinics that offer help to people addicted and co-addicted to alcohol. The scope of activities of such clinics includes: diagnosing addicted people and diagnosing disorders in their family members, completing corrective programmes for example for drivers who lost their driving licence; psychotherapy for people addicted to alcohol and other psychoactive substances; programmes for people with habit and drive disorders; programmes for family members affected by the consequences of one's alcohol use or use of other psychoactive substances; programmes for family members of people with habit and drive disorders. Those clinics also provide preventive and rehab services, consultations and educational activities for family members.

On the other hand, 24-hour alcohol addiction rehab wards and 24-hour addiction rehab wards carry out tasks that are the same as those of alcohol addiction and co-addiction rehab clinics and addiction rehab clinics, and operate all day long, at the same time preparing a patient to continue therapy in those clinics. It is also worth mentioning day-care alcohol addiction rehab wards and day-care addiction rehab wards that carry out the above-mentioned tasks related to addicted people and prepare patients to start therapy in those clinics. In the Polish system, there are also wards for treating alcohol abstinence syndromes that are obliged to: diagnose disorders caused by alcohol use or use of other psychoactive substances; alcohol rehab or post-medicine abstinence syndrome rehab, and motivate patients to take up addiction psychotherapy. ${ }^{40}$

${ }^{39}$ E. Włodarczyk, Osoby uzależnione od alkoholu w polskim systemie(?) wsparcia społecznego, [w:] Od wykluczenia do wsparcia. W przestrzeni wspótczesnych problemów społecznych, red. J. Spętana, D. Krzysztofiak, E. Włodarczyk, Kraków 2016, p. 117.

${ }^{40}$ In line with the Directive of the Minister of Health of 25 June 2012 (Journal of Law 2012, item 734) on the organization, staff's qualifications, way of functioning and types of rehab facilities providing full-time, 24-hour and outpatient services for those addicted to alcohol and on cooperation methods with this respect with public institutions and social organizations, $\S 3$ point 2, facilities can operate as alcohol addiction rehab clinics if they provide:

1) Full-time and outpatient health services for those addicted to alcohol and their family members, or

2) Outpatient health services for those addicted to alcohol and their family members, and the clinic includes:

a) A darecare alcohol addiction rehab ward or a daycare addiction rehab ward and

b) A counselling service for alcohol addiction and co-addiction rehab or a counselling service for addiction rehab. 
Thanks to hostels, it is possible to ensure independent functioning in the environment, i.e. integration with the local community, as well as completing rehab programmes focused on increasing social competence and independent functioning of addicted people. They provide conditions for independent functioning in the environment, help integrate with the local community and they complete a rehab programme directed at increasing social competence and independent functioning of addicted people. In order to be admitted to a hostel, one is usually required to have completed basic treatment and be a teetotaller.

In Poland, it is also possible to receive treatment from non-governmental organizations that help those addicted and thus create an option for those addicted to alcohol to self-organize. It is important because mutual aid groups create an opportunity for emotional and social support and understanding. They also provide one with a sense of being accepted and show ways of developing one's ability to deal with their problem. It is also a place where an addicted person can relieve their emotions, and above all broaden their knowledge on their problem and build a network of contacts that they will need in order to deal with it. Among others, this idea is used in the Alcoholics Anonymous (AA) community whose aim is to create a group that will make it possible for one to stay sober and support others to become a teetotaller. It is voluntary to participate in it; support is provided to women and men, and the only condition to participate is to stop drinking. The community is not linked to any religion or political organization; it is self-sufficient, and thus open to everyone who starts their fight with their addiction..$^{41}$ For people who tackle the problem of their partner's addiction, it is typical to share their experience, draw energy and hope to solve their problem. Al-Anon groups are based on the programme of 12 steps and 12 traditions, and recognized as a form of mutual aid for people who notice their partner's problem and at the same time try to learn from each other to function in a way that will not be damaging for them; quite contrary, that will allow them to function in a satisfying way. The successes of these groups, and above all the openness of people who decide to share their problem with others, led to the creation of other groups whose

${ }^{41}$ B.T. Woronowicz, Uzależnienie. Geneza, terapia, powrót do zdrowia, Warszawa 2009, p. 279280. AA was created in the United States, and BillW. (William Griffith Wilson) and Boba (Robert Holbrook Smith) are believed to be its founders. The first day of his uninterrupted soberness on June 10, 1935 is considered to be the date this movement was born. The "Alcoholics Anonymous" book published in 1939 that described experiences of those addicted was the inspiration for the name of the movement. Information about AA reached Poland a bit later, around 1957, thanks to Zbigniew Wierzbicki, who published 12 Traditions in the Poznan "Health and Soberness" (Polish "Zdrowie i Trzeźwość") magazine. What is interesting is that the censorship banned 12 Steps as they included a reference to God. In Poznan, the AA movement developed thanks to Maria Grabowska who started to give group classes based on the 12 Steps programme in the late 1960s. The group's independent functioning is dated 1974 and this year is considered as the beginning for the Polish AA. 
members are alcoholics' children, both those younger (Alatot, Alakid) and adolescents (Alateen). Due to the awareness that functioning in a family with the alcohol problem is distant from a normal reality of a child, those groups have been recognized as important for helping the youngest family members. The experience of trauma, unsatisfied needs, developmental negligence and disrupted bonds in significant relations, especially with one's parents and guardians, have all become elementary factors pointing to the need to (in some cases) to function in a support group for Adult Children of Alcoholics (ACoA). However, not every person brought up in a family with the alcohol problem requires psychotherapy. AcoAs include people who need psychological help in crisis situations; there are also people with the ACoA syndrome and unadjusted people with some psychic disorders who have to deal with addictions, anxiety disorders, neurosis symptom syndromes, personality disorders and other psychopathological syndromes. ${ }^{42} \mathrm{~T}$. Kulisiewicz underlines that it is important to function in support groups due to the assumption that even if it is impossible to rescue the person addicted, it is necessary to save their family members who should encounter and accept a new lifestyle regardless of the alcoholic's actions. ${ }^{43}$ The Association for the Prevention and Counteracting Addictions is an example of how addicted people and their families can be supported. Its activities focus on counteracting addictions and addiction-related forms of social pathology among children, adolescents and adults. The KARAN Foundation Helping Children and Addicted People serves as yet another example; it also provides help to people from families that need help where there are individuals who are addicted and at risk from an addiction. The foundation's activities focus on promoting a pattern of a stable and healthy family and society, and providing legal help. Those addicted can also seek help at counselling points, teetotaller clubs and helplines. Information and contact points usually offer an AA helpline, an AA hotline, an online emergency site, as well as notices and information on AA groups.

Quite a lot of alcohol addiction rehab facilities still use therapeutic programmes based on the so-called Minnesota model. This method was developed in the USA and adapted to Polish conditions in 1980s. It is based on the assumption that alcoholism is an illness and alcoholics should be treated, not punished. Alcoholism is a chronic illness that requires a specific treatment method irrespective of its causes; it is an illness that leads to disorders in many spheres of an individual's functioning. There is thus a need to provide an addicted person with help in many aspects of their life. The method states that motivation is not a prerequisite for achieving positive therapy effects,

${ }^{42}$ Państwowa Agencja Rozwiązywania Problemów Alkoholowych, www.parpa.pl [Accessed: 18.12.2017].

${ }^{43}$ T. Kulisiewicz, Choroba alkoholowa, Warszawa 1973, p. 144-145. 
because its elementary syndrome is denial that appears on various stages of sobering up. It is a programme that underlines the need to help an ill person deal with their illness. It is the ill person themselves who is involved, but they use the knowledge and experience of therapists and the support of their family. The small groups where they function give them the option to work both individually and in group. ${ }^{44}$

At alcohol addiction rehab facilities in Poland, psychotherapy dealing with mechanisms responsible for developing an illness is a form of help. The psychotherapeutic programme was developed in a way that makes it possible for the patient to achieve constructive improvement in their psychosocial functioning at every stage of the therapy. Changes that occur during the psychotherapy that one undergoes are a long process and require adjusting appropriate methods and therapeutical interventions to the period of time that the organism of the addicted person needs to reach balance. ${ }^{45}$

Specialists who deal with addiction therapy point out that the following factors influence the rehab process of those addicted irrespective of the place where they are treated:

a. Family stability - having a close relationship with someone is regarded as the strongest predicate for effective treatment.

b. Happy marriage - studies show that people who start therapy and have already got divorced give up on their therapy more frequently.

c. Good relations with children - higher motivation and energy levels among women who have children as compared to those who don't.

d. Friends' loyalty - it is especially important among men and positively influences the chance of abstaining from alcohol for a longer period of time.

e. Sense of security/closeness with one's partner - it is crucial whether an addicted person's partner who lives together with them abstains from alcohol.

f. Stable job - having or finding a job motivates one to abstain from alcohol.

g. Good communication skills - completing a programme that supplements interpersonal deficits is an important factor linked to abstinence.

h. Self-development via education or professional training - people who are less educated are less prone to use help at rehab facilities as compared to those with higher education.

i. Being engaged at church or a religious community - patients who use work methods linked to the spiritual dimension are more successful at abstaining from alcohol.

${ }^{44}$ E. Silecka, Alkoholizm. Problem indywidualny czy problem społeczny? [w:] Człowiek wobec krytycznych sytuacji życiowych. Z teorii i praktyki pracy socjalnej, red. E. Włodarczyk, I. Cytlak, Poznań 2011, p. 277-278.

${ }_{45}$ R. Modrzyński, Abstynencja czy ograniczenie picia. Znaczenie zasobów w przewidywaniu abstynencji osób uzależnionych od alkoholu we wczesnej fazie zdrowienia, Warszawa 2017, p. 92. 
$j$. Therapeutic relation between the patient and the therapist - the better the relation with their therapist, the more engaged the patient is.

k. Personal management resources - when healing, the level of neuroticism decreases and conscientiousness is on the increase ${ }^{46}$.

In Poland, treating addicted people has been conditioned by the progress in medical and psychological knowledge, as well as social and political atmosphere. There have been times when they either fostered or hindered the development of facilities aimed for those addicted. The forms of assistance provided seem to favour giving up on one's addiction, yet it remains problematic for the patients to abstain from alcohol for good.

Despite their positive motivation to be treated, some patients are quick to return to their addiction. Others, on the other hand, return to drinking after many months, or even years, of total abstinence (...). Still, in some cases patients who for many years have been finding it very difficult to abstain from alcohol stop drinking (...). What is decisive for a patient's attitude in such cases still remains unknown. ${ }^{47}$

\section{Conclusions}

Despite formally described proceedings related to alcohol-addicted people, diagnosing procedures set by law, the obligation to treat and treatment itself, and cooperation of many entities, activities related to addicted people are often ineffective.

The procedure of obliging alcohol-addicted people to undergo rehab treatment is not efficient and does not support solving alcohol problems in Poland effectively. Most defendants (over 60 per cent) do not start treatment. 30 per cent of those admitted to undergo obligatory treatment (on the basic level) do not complete it. Half of the defendants are sent to compulsory rehab again. ${ }^{48}$

Few of those addicted obliged to undergo treatment by court continue their therapy in extensive therapy programmes.

${ }^{46}$ Ibidem, p. 87.

47 T. Kulisiewicz, Alkoholizm - to także choroba, Warszawa 1969, p. 110-111. What criteria should thus be followed when choosing a therapy for etery patient? Projekt MATCH, the largest study on the effectiveness of therapy of addictions to date, investigated into three completely different approaches and verified 21 hypotheses on which therapy is best for which patient. As it turned out, specialists in a given domain were unable to foresee or indicate it. No approach is sufficiently good for all patients; yet, taking up any kind of therapy, even if short-termed, is better than none for sure. It is thus important who runs the therapy and how they communicate with their patients. More in: C. Barański, Dialog motywujacy.

${ }^{48}$ Przymusowe kierowanie osób uzależnionych od alkoholu na leczenie odwykowe, Warszawa 2016, p. 8 . 
Thus, the compulsory character of rehab treatment sparks a lot controversy, as it contradicts the right to self-determination, i.e. independent decision of the person addicted to take up treatment. There is a need to seek new solutions in this respect, develop tools that increase the effectiveness of activities taken towards those addicted and exchange experiences on the global scale.

Help provided to an addicted person and their family has to be individualized, focused on supporting solving the basic problem, i.e. the addiction, which generates other problems in the person's functioning that require support (poverty, unsatisfied sense of security, emotional and psychic disorders, etc.).

Support can be either immaterial (diagnosis, treatment, therapy, counselling, social work with the addicted person, their family and environment) or material (which consists in paying benefits defined by law that makes it possible to satisfy elementary needs provided that the beneficiary fulfils the conditions defined by law).

The tripolarity of handling people with the alcohol problem requires a cooperation-based participation of a court-appointed guardian who carries out the supervision adjudicated by court, appropriate selection of institutions providing those addicted and their families with support, and effective legal solutions that make it possible to act in this respect.

The help in question should be multifaceted, based on respecting the free will and dignity of those tackling an addiction and their families.

\section{BIBLIOGRAPHY}

American Psychiatric Association. Diagnostic and statistical manual of mental disorders (DSM-5), APA, Washington 2013.

Bałandynowicz A., Probacja. Wychowanie do wolności, Grodzisk Mazowiecki 1996.

Bałandynowicz A., Destygmatyzacja tożsamości dewiantów jako zmiana czasowa i interpersonalna w polifunkcyjnym modelu probacji, [w:] Tożsamość osobowa dewiantów a ich reintegracja społeczna, cz. L, red. A. Kieszkowska, Kraków 2011.

Barański C., Dialog motywujący w pracy z grupami osób podejmujących zachowania ryzykowne, Psychoterapia, 2016, 3.

Cierpiałkowska L., Ziarko M., Psychologia uzależnień - alkoholizm, Warszawa 2010.

Heitzman J., Łoza B., Kosmowski W., Classification of mental disorders - a conceptual framework for the ICD11, Psychiatria Polska 2011.

http://www.parpa.pl/images/file/szkolenia_srodek_09_06.pdf.

http://www.parpa.pl/index.php/badania-i-informacje-statystyczne/statystyki.

Jaraczewska J.M., Adamczyk-Zientara M. (red.), Dialog motywujący. Praca z osobami uzależnionymi behawioralnie, Warszawa 2015.

Jedynak T., Stasiak K. (red.), Zarys metodyki kuratora sądowego, Warszawa 2014.

Kalinowski M., Vademecum rodzinnego kuratora sądowego, Warszawa 1984.

Kulisiewicz T., Alkoholizm - to także choroba, Warszawa 1969. 
Kulisiewicz T., Choroba alkoholowa, Warszawa 1973.

Lalak D., Teoretyczny i praktyczny sens metody indywidualnych przypadków, [w:] Pedagogika społeczna, red. T. Pilch, L. Lepalczyk, Warszawa 1995.

Łukowska K., Zobowiazzanie do leczenia odwykowego - informator dla rodzin, Fundacja ETOH Warszawa 2014.

Miller R.W., Rollnick S., Dialog motywujący. Jak pomóc ludziom w zmianie, Kraków 2014.

Modrzyński R., Abstynencja czy ograniczenie picia. Znaczenie zasobów w przewidywaniu abstynencji osób uzależnionych od alkoholu we wczesnej fazie zdrowienia, Warszawa 2017.

Ostrihanska Z., Greczuszkin A., Praca z indywidualnym przypadkiem w nadzorze rodzinnego kuratora sadowego, Lublin 2000.

Pospiszyl I., Patologie społeczne, Warszawa 2008.

Przymusowe kierowanie osób uzależnionych od alkoholu na leczenie odwykowe, Najwyższa Izba Kontroli, Warszawa 2016.

Rozporządzenie Ministra Zdrowia z 25 czerwca 2012 r. (DzU 2012, poz. 734), w sprawie organizacji, kwalifikacji personelu, sposobu funkcjonowania i rodzajów podmiotów leczniczych wykonujących świadczenia stacjonarne i całodobowe oraz ambulatoryjne w sprawowaniu opieki nad uzależnionymi od alkoholu oraz sposobu współdziałania w tym zakresie z instytucjami publicznymi i organizacjami społecznymi.

Rozwiązywanie problemów alkoholowych w gminie - ramowy program szkolenia dla gminnych komisji rozwiązywania problemów alkoholowych, Państwowa Agencja Rozwiązywania Problemów Alkoholowych, Warszawa 2016. http://www.parpa.pl/ images/file/szkolenia_srodek_09_06.pdf [accessed: 18.12.2017].

Sawicka K., Probacyjne środki w profilaktyce i resocjalizacji nieletnich, [w:] Probacyjne środki polityki karnej - stan i perspektywy, oprac. B. Cichońska, Warszawa 2001.

Sierosławski J., Używanie alkoholu i narkotyków przez młodziė̇ szkolnq, Raport z ogólnopolskich badań ankietowych zrealizowanych w 2015 r., Europejski Program Badań Ankietowych w Szkołach, ESPAD.

Silecka E., Alkoholizm. Problem indywidualny czy problem społeczny? [w:] Człowiek wobec krytycznych sytuacji życiowych. Z teorii i praktyki pracy socjalnej, red. E. Włodarczyk, I. Cytlak, Poznań 2011.

Ustawa z 25 lutego 1964 r. Kodeks rodzinny i opiekuńczy (DzU 2017 r. poz. 682 ze zm.).

Ustawa z 26 października 1982 r. o wychowaniu w trzeźwości i przeciwdziałaniu alkoholizmowi (DzU 2016 r. poz. 487 ze zm.).

Węgliński A., Zasoby osobiste i kompetencje zawodowe kuratorów sądowych niezbędne w pracy z osoba dozorowana z problemem alkoholowym, Lubelski Rocznik Pedagogiczny, 2013, XXXII.

Węgliński A., Motywowanie skazanych z problemem alkoholowym do samowychowania w warunkach wolnościowych, Lubelski Rocznik Pedagogiczny, 2014, XXXIII.

Węgliński A., Kuziora G., W poszukiwaniu wychowującej kurateli sądowej, Lublin 2016.

Włodarczyk E., Osoby uzależnione od alkoholu w polskim systemie(?) wsparcia społecznego, [w:] Od wykluczenia do wsparcia. W przestrzeni wspótczesnych problemów społecznych, red. J. Spętana, D. Krzysztofiak, E. Włodarczyk, Kraków 2016.

Włodarczyk E., Społeczny wymiar problemu alkoholowego kobiet. Obraz i instytucjonalne reakcje środowiska wielkomiejskiego, Poznań 2017.

Woronowicz B.T., Uzależnienie. Geneza, terapia, powrót do zdrowia, Warszawa 2009.

Zgliczyński W.S., Alkohol w Polsce, INFOS Zagadnienia społeczno-gospodarcze, 2016, 11(215). 
